\title{
EL POTENCIAL TERRITORIAL COMO FACTOR DEL DESARROLLO. MODELO PARA LA GESTIÓN RURAL
}

\author{
TERRITORIAL POTENTIAL AS FACTOR OF DEVELOPMENT: RURAL \\ MANAGEMENT MODEL
}

Jimena V. Lee-Cortés, Javier Delgadillo-Macías*

\begin{abstract}
Unidad de Investigación en Economía Urbana y Regional del Instituto de Investigaciones Económicas de la UNAM. (arqlee09@gmail.com), (javierdelma@gmail.com).
\end{abstract}

\section{$\begin{array}{ll}\text { Resumen } & \text { AbSTRact }\end{array}$}

\begin{abstract}
Ante los problemas que enfrenta el medio rural en la última década se han promovido instrumentos encaminados a su solución; sin embargo, los aportes institucionales han sido limitados y poco favorables para el mejor desenvolvimiento de los territorios. No obstante, se reconocen estos esfuerzos como referentes para la reorientación de la política pública dirigida al sector rural. El objetivo del trabajo es mostrar que los potenciales de desarrollo y los programas públicos con posible impacto requieren de propuestas metodológicas que sean sensibles a los componentes de la estructura productiva y social, y a los problemas que impiden mejorar las condiciones de vida de la población rural y promover el desarrollo territorial. Para ello se emplea un modelo de interacción socio-espacial que muestra las características de las actividades y recursos locales, así como del papel de la acción pública, social y privada como factores integradores de desarrollo de los territorios seleccionados.
\end{abstract}

Palabras clave: desarrollo rural, gestión territorial, interacción socio-espacial, programas rurales, potenciales territoriales de desarrollo.

\section{INTRODUCCIÓN}

$\mathrm{E}$ n México, numerosos territorios se encuentran en una crisis que data de al menos 30 años, provocando un fenómeno de marginación económica y exclusión social que se agrava progresivamente. Las familias campesinas representan una cuarta parte de la población nacional y la pobreza afecta a más de $60 \%$ de ellas; dos de cada tres habitantes en el sector rural viven en zonas de alta marginación, no cuentan con servicios básicos de

* Autor responsable * Author for correspondence.

Recibido: febrero, 2016. Aprobado: diciembre, 2016.

Publicado como ARTÍCULO en ASyD 15: 191-213. 2018.
In view of the problems faced by the rural environment in the last decade, instruments have been promoted that are leading towards their solution; however, institutional contributions have been limited and unfavorable for a better development of the territories. Nevertheless, these efforts are recognized as models for the reorientation of the public policy directed at the rural sector. The objective of this study is to show that the potentials for development and public programs with possible impact require methodological proposals that are sensitive to the components of the productive and social structure, and to the problems that prevent improving the living conditions of the rural population and promoting territorial development. For this purpose, a model of sociospatial interaction that shows the characteristics of the local activities and resources, as well as the role of public, social and private action as integrating factors of development for the territories selected.

Key words: rural development, territorial management, sociospatial interaction, rural programs, territorial potentials for development.

\section{INTRODUCTION}

$\mathrm{I}$ n México, many territories are in the midst of a crisis that dates back at least 30 years, provoking a phenomenon of economic marginalization and social exclusion that is progressively aggravated. Peasant families represent a fourth part of the national population and poverty affects more than $60 \%$ of them; two out of three inhabitants in the rural sector live in high marginalization zones, do not have basic services of water, drainage, electric energy, and lack access to education and elemental health services. In addition, sustaining economic activities is not very promising and a condition is 
agua, drenaje, energía eléctrica, y carecen de acceso a la educación y servicios de salud elementales. Además, el sostenimiento de actividades económicas es poco prometedor y se observa en una condición donde con mayor frecuencia las estrategias de desarrollo económico privilegian el papel de las ciudades, toda vez que la distribución geográfica de las localidades rurales es muy dispersa $(67.8 \%$ de las localidades son menores a 50 habitantes). Asimismo, en las zonas rurales se registra rezago en materia de infraestructura básica y productiva, que entre otras consecuencias incrementa el abandono del territorio por parte de sus habitantes, desencadena un patrón elevado de migración de la población económicamente activa y produce una escasa capitalización al interior de las comunidades. En este contexto de asimetrías entre actores y lugares resulta impostergable promover un desarrollo local participativo, a partir de la implantación de un modelo de economía basado en los potenciales endógenos de los propios territorios.

La situación de crisis del medio rural mexicano es resultado del modelo de apertura comercial donde los gobiernos apostaron al crecimiento económico, posponiendo las políticas públicas de carácter social y solidario, dejando pendiente el bienestar de la población (Calva, 2004). Bajo este modelo y de acuerdo con Echeverri (INCA Rural, 2009), las políticas públicas orientadas al medio rural se han instrumentado en dos sentidos; por un lado, aquellas con un enfoque hacia sectores con mayores capacidades y dirigidas básicamente a los productos y, por otro, las canalizadas a los sectores de población más desfavorecidos en torno a los actores sociales, manteniendo enfoques asistencialistas.

En la actualidad, si bien se han adoptado nuevos modelos donde el objeto de atención ha cambiado hacia la figura del territorio como sujeto específico de las políticas públicas, la lógica de acción institucional permanece en muchos casos en el orden sectorial con escalas de acercamiento político-administrativas y parámetros que responden a estas últimas. Las políticas como instrumento de fortalecimiento para el desarrollo de los territorios cuentan con un papel y un impacto incierto; se observa que la escala, es decir, el nivel territorial en el que se ubican para su diseño, resulta generalizadora, por lo que se pierden de vista especificidades que dan forma a las comunidades, al tiempo que se genera en los beneficiarios dependencia de las transferencias de recursos públicos. observed where with higher frequency the strategies of economic development privilege the role of the cities, insofar as the geographic distribution of rural localities is quite disperse $(67.8 \%$ of the localities are smaller than 50 inhabitants). Likewise, in the rural zones there is backwardness in matters of basic and productive infrastructure, which among other consequences increases the abandonment of the land by its inhabitants, unleashes a pattern of high migration of the economically active population, and produces scarce capitalization inside the communities. Within this context of asymmetries between actors and places it is urgent to promote a participative local development, stemming from the implementation of a model of economy based on the endogenous potentials of the territories themselves.

The crisis situation of the Mexican rural environment is the result of the model of commercial openness where governments wagered on economic growth, postponing the public policies of social and solidary nature, leaving pending the welfare of the population (Calva, 2004). Under this model and according to Echeverri (INCA Rural, 2009), the public policies directed at the rural environmental have been implemented in two senses; on the one hand, those with an approach towards sectors with higher capacities and directed basically at products and, on the other hand, those channeled to the most disadvantaged sectors of the population around social actors, maintaining handout mentality approaches.

Recently, although new models have been adopted where the object of attention has changed towards the figure of territory as a specific subject for public policies, the logic of institutional action remains in many cases within the sectorial order with scales of political-administrative rapprochement and parameters that respond to the latter. Policies as strengthening instrument for the development of the territories have an uncertain role and impact; it is observed that the scale, that is, the territorial level in which they are located for their design, is generalizing, which is why specificities that shape the communities are overlooked, at the same time that dependency is generated in the beneficiaries on the transference of public resources.

In particular, rural communities in the states of Oaxaca and Guerrero, study subject of this research, are among the most backward of the country and characterized by having activities based on economies 
En particular, las comunidades rurales de los estados de Oaxaca y Guerrero, objeto de estudio de la presente investigación, se encuentran entre las más rezagadas del país y se caracterizan por sostener actividades basadas en economías de recursos naturales o de transformación ${ }^{1}$. Ambas entidades, situadas al sur del país, cuentan con importantes recursos potenciales derivados de su riqueza natural y medioambiental, y al desarrollo de actividades ligadas con la cultura de sus pueblos, lo que les ha valido recibir a lo largo de los ańos beneficios derivados de la amplia oferta de programas públicos dirigidos a sus comunidades. Sin embargo, la mayoría de estos solo sirven como paliativos con casi inexistentes acciones de carácter integral, dando como resultado que se limiten las capacidades de promoción local y la autogestión de grupos y comunidades; asimismo, existe una corresponsabilidad por parte de los actores locales, las comunidades, las organizaciones sociales, quienes tampoco han sido capaces de proponer un modelo o enfoques de participación que favorezcan el desarrollo de sus entornos, asumiendo de manera irreflexiva las políticas asistencialistas.

\section{La dimensión territorial y el enfoque de gestión}

El presente trabajo tiene como objetivo desarrollar un modelo metodológico orientado a detectar las posibilidades de desarrollo existentes en comunidades del ámbito rural, basado en el comportamiento del sistema de funciones y relaciones económicas, sociales, ambientales e institucionales a partir de un enfoque de gestión territorial. La noción de desarrollo propuesta refiere a un proceso que provee crecimiento y generación de riqueza a la comunidad, como resultado de procesos sostenidos de cohesión social y territorial y del análisis de los actores sociales, quienes a través de su diversidad, intereses y valores influyen en la dinámica y conformación del propio territorio.

La gestión del desarrollo en el territorio es un proceso presente; no obstante, los efectos son limitados respecto a una verdadera incidencia en las condiciones de sus habitantes, así como de sus recursos. Ello provoca que la configuración del territorio atienda de forma marginal las problemáticas respecto de las necesidades y sus potenciales, lo cual nos lleva a pensar que el problema se ubica en dos sentidos; por un lado, la incidencia que existe sobre el desarrollo territorial, a of natural resources or transformation ${ }^{1}$. Both entities, located south of the country, have important potential resources derived from their natural and environmental wealth, and to the development of activities linked to the culture of their peoples, which has meant for them to receive benefits throughout the years derived from the broad offer of public programs directed at their communities. However, most of these only serve as palliatives with almost nonexistent actions of integral character, giving as a result that the capacities of local promotion and selfmanagement of groups and communities become limited; likewise, there is co-responsibility by local actors, communities, social organizations, who also have not been able to propose a model or participation approaches which favor the development of their surroundings, assuming handout policies in a rash manner.

\section{The territorial dimension and management approach}

This study has the objective of developing a methodological model directed at detecting the possibilities of development present in communities of the rural environment, based on the behavior of the system of functions and economic, social, environmental and institutional relations from an approach of territorial management. The notion of development proposed refers to a process that provides growth and wealth generation to the community, as a result of processes sustained of social and territorial cohesion, and of analysis of the social actors, who through their diversity, interests and values influence the dynamics and conformation of the territory itself.

Development management in the territory is a process that is present; however, the effects are limited with regards to a real influence on the conditions of its habitants, as well as its resources. This provokes for the configuration of the territory to address marginally the problematic regarding the needs and its potentials, which leads us to consider that the problem is located in two senses; on the one hand, the influence present on territorial development, through the actions of public policies, specifically those related to the planning of development. On the other hand, the territory's possibility, specifically the actors, of configuring and managing its development, 
través de las acciones de política pública, específicamente las relacionadas con la planeación del desarrollo. Por el otro, la posibilidad que tiene el territorio, específicamente los actores, de configurar y gestionar su desarrollo, aprovechando los potenciales internos, así como las iniciativas públicas y privadas que inciden en su desenvolvimiento.

Se propone un modelo compuesto por dimensiones temáticas que contempla una revisión sobre el efecto de la inversión pública o privada (a la cual denominamos incidencia) ejercida a través de los programas que se aplican en las comunidades e incorporando como indicador el aprovechamiento de los recursos con que cuentan. Se basa en un concepto de integralidad que, como señala el modelo metodológico aplicado por el INCA Rural (2009:8), implica considerar a la organización económica del territorio como una estructura funcional de carácter multisectorial donde interactúan diversidad de instituciones basadas en el patrimonio cultural, político e histórico de los territorios. Se aborda al individuo desde su percepción colectiva, que conlleva la interacción social con su entorno, reglas, costumbres e intereses comunes, expresados en el territorio vivencial. A estas relaciones que se establecen a partir de atributos sociales (participación, actores e instituciones) y territoriales (factores locacionales, indicadores regionales y recursos locales) les denominamos interacciones socioespaciales. En el mismo sentido, Claude Grasland (2013) señala que para la geografía humana las relaciones entre lugares, ya sea que se trate de ciudades, de regiones o del estado, se refieren a agregados sociales o económicos localizados, la mayoría de las veces heterogéneos, compuestos por individuos (personas, parejas, empresas,...) que no disponen de los mismos ingresos, de las mismas capacidades de movilidad, de la misma información sobre las oportunidades de relación distantes ${ }^{2}$.

El territorio rural es el espacio apropiado, producido y dotado de significado. Es una unidad espacial negociada colectivamente, resultado de procesos históricos y acciones conducidas por los actores, ya sean agentes o sujetos en cualquier nivel, sobre la apropiación social de espacios construidos alrededor del uso y aprovechamiento de los recursos del lugar. En estos casos las políticas de desarrollo actúan como estrategia para el uso de dichos recursos y el fomento de las capacidades en los distintos campos de actuación, a través de programas encargados de favorecer taking advantage of internal potentials, as well as public and private initiatives that have an impact on its development.

A model composed by thematic dimensions that contemplates a review of the effect of public or private investment is proposed (which we call influence), exerted through the programs that are applied in the communities and incorporating as an indicator the exploitation of the resources available. It is based on a concept of integrality which, as is pointed out in the methodological model applied by the INCA Rural (2009:8), implies considering the economic organization of the territory as a functional structure of multi-sectorial character where a diversity of institutions interact based on the cultural, political and historical heritage of territories. The individual is addressed from his/her collective perception, which entails social interaction with his/her environment, regulations, customs, and common interests, expressed in the experiential territory. These relationships that are established from social (participation, actors and institutions) and territorial (location factors, regional indicators and local resources) attributes are known as socio-spatial interactions. In this same sense, Claude Grasland (2013) points out that for human geography, the relationships between places, whether these are cities, regions or the state, refer to localized social or economic aggregates, most times heterogeneous, composed by individuals (people, couples, enterprises, ...) that do not dispose of the same income, the same capacities for mobility, or the same information on the distant opportunities for relation ${ }^{2}$.

The rural territory is the space appropriated, produced and endowed with meaning. It is a spatial unit collectively negotiated, resulting from historical processes and actions led by actors, whether agents or subjects at any level, on the social appropriation of spaces built around the use and exploitation of the resources in the place. In these cases the development policies act as a strategy for the use of these resources and the promotion of capacities in different fields of action, through programs in charge of favoring the relationships between actors and promoting interactions between common territories. However, the agreement between government programs applied and development in rural territories is not clear if we consider persistent difficulties, such as the abandonment of communities and the low 
las relaciones entre los actores y promover interacciones entre territorios comunes. Sin embargo, la concordancia entre los programas gubernamentales aplicados y el desarrollo en los territorios rurales no es clara si consideramos problemáticas persistentes, como el abandono de las comunidades y los bajos perfiles productivos en que se ubican los productores de dichos ámbitos.

La propuesta que planteamos busca redimensionar a los territorios rurales más allá de ser meros poseedores de recursos naturales, para lo cual se retoma su análisis a través de un acercamiento a los potenciales con que cuentan y se observa cómo se vinculan con las acciones implementadas por las políticas públicas a través de programas de asistencia y fomento rural, en términos de ser vehículos para el desarrollo de las comunidades.

Entendemos como potenciales territoriales las capacidades de los habitantes del territorio, las redes con que se encuentran vinculados los procesos de trabajo y vida, así como la participación de las instituciones locales en la configuración del desarrollo y las actividades diarias, con esquemas participativos e incluyentes. De acuerdo con Horton Douglas (2008), el potencial parte de que los conocimientos, habilidades, actitudes, valores, relaciones, motivaciones y condiciones, permiten a individuos, organizaciones, redes sociales, sectores e instituciones el desempeño de sus funciones y alcanzar objetivos planteados para su desarrollo, pero también los de desarrollo son elementos que componen la estructura del territorio, partiendo de rasgos físicos a elementos identitarios que definen y distinguen características de un territorio a otro. Hacen referencia a los recursos, la distribución de los modos de vida de la sociedad, la disponibilidad de conocimientos especializados adecuados, la eficiencia de la administración local, la eficacia de los vínculos entre territorios y la capacidad relativa de la gente de participar en mercados nacionales e internacionales.

El cálculo del potencial territorial de un lugar se basa en la consideración de una hipótesis de interacción socioespacial como medida de accesibilidad que apunta a evaluar la variación favorable de la cantidad de oportunidades locales en función de la ubicación del lugar o la región y de las capacidades internas desarrolladas.

La determinación de los potenciales de cada lugar deriva de diagnósticos territoriales integrales en su productive profiles in which producers of these areas are found.

The proposal we set out seeks to re-dimension the rural territories beyond them being mere owners of natural resources, for which their analysis is taken up again through an approach to the potentials they have and the way that they are linked to the actions implemented by public policies through handout and rural promotion programs, in terms of being vehicles for the development of communities.

We understand as territorial potentials the capacities of the territory's inhabitants, the networks with which the processes of work and life are linked, as well as the participation of local institutions in the configuration of development and daily activities, with participative and inclusive schemes. According to Horton Douglas (2008), the potential stems from the fact that knowledge, abilities, attitudes, values, relations, motivations and conditions allow individuals, organizations, social networks, sectors and institutions the performance of their functions as well as reaching objectives set out for their development, although development elements also make up the territory's structure, starting from physical features to identity elements that define and distinguish characteristics of one territory from another. They refer to the resources, the distribution of livelihoods in society, the availability of adequate specialized knowledge, the efficiency of local administration, the efficacy of connections between territories, and the relative capacity of people to participate in national and international markets.

Calculating the territorial potential of a place is based on the consideration of a hypothesis of sociospatial interaction as a measure of accessibility that points to evaluating the favorable variation of the amount of local opportunities in function of the location of the place or the region and of the internal capacities developed.

The determination of the potentials in each place derives from integral territorial diagnoses in their functional dimension, although differentiated in terms of the processes that should be addressed. According to Coraggio (2004:16), a methodological problem that is present when performing a diagnosis is to determine what concrete segment of the social reality will be the object of analysis and under which criteria will it be carried out. Therefore, in the first place, it is about recognizing the type of relations and 
dimensión funcional, pero diferenciados en cuanto a los procesos que deben atenderse. De acuerdo con Coraggio (2004:16), un problema metodológico que se presenta al realizar un diagnóstico es determinar qué segmento concreto de la realidad social será el objeto de análisis y bajo qué criterios se realizará. Por ello, en primer lugar se trata de reconocer el tipo de relaciones y factores sociales que dan especificidad a cada programa, abordados aquí como potenciales del territorio. En segundo lugar, se trata de tipificar un conjunto de actores sociales insertos en tales relaciones o situaciones, en relación con los cuales se produciría la intervención concreta. Hablamos en este caso de actores económicos representativos de cada actividad identificada en las comunidades de estudio. En el sentido que plantea Coraggio, el diagnóstico se convierte en elemento fundamental del proceso de gestión territorial al reconocer problemáticas y causalidades diferenciadas que deben ser abordadas mediante procesos también específicos a cada situación.

La gestión territorial debe atravesar por un proceso que conduzca a los actores y agentes hacia la apropiación de sus potenciales, la reproducción de estos y la incorporación de elementos de innovación tecnológica, productiva y social. Pasa de ser una labor administrativa gubernamental a un proceso de participación, coordinación y negociación de los agentes del territorio sobre la base de sus potenciales. La incorporación de estos cambios en la gestión implica la adopción y desarrollo de innovaciones en la estructura del territorio, constituyendo, como indica Alburquerque (1994: 316), un proceso de cambio social, organizativo y cultural, más allá de cambios tecnológicos en la producción.

La planeación y la gestión territorial requieren que el análisis y las intervenciones sobre el territorio se desenvuelvan con una visión acorde a la organización del territorio a partir de enfoques multidisciplinarios. Los mecanismos de gestión territorial serán participativos y no solo normativos, integrando la planificación física y el desarrollo económico.

Las acciones públicas dirigidas a los territorios rurales se encuentran determinadas por información $y$, en particular, sobre indicadores que no están acorde con la escala de necesidades y aportes que tienen y hacen los territorios rurales; por ello, la metodología contempla abordar las actividades productivas de las personas inmersas en el contexto rural y su acción e interacción como componentes del sistema territorio. social factors that give specificity to each program, addressed here as potentials for the territory. In the second place, it is about typifying a set of social actors inserted in such relationships or situations, in relation to which the concrete intervention would be produced. We speak in this case of representative economic actors from each activity identified in the communities of study. In the sense that Coraggio suggests, the diagnosis becomes a fundamental element of the territorial management process when recognizing differentiated difficulties and causalities that should be addressed through processes that are also specific to each situation.

Territorial management must go through a process that leads actors and agents towards the appropriation of their potentials, their reproduction and the incorporation of elements of technological, productive and social innovation. It goes from being a government administrative task to a process of participation, coordination and negotiation of the agents in the territory on the basis of their potentials. The incorporation of these changes in the management implies the adoption and development of innovations in the structure of the territory, constituting a process of social, organizational and cultural change, as Albuquerque (1994: 316) points out, beyond technological changes in the production.

Territorial planning and management requires that the analysis and interventions on the territory develop with a vision according to the organization of the territory from multidisciplinary approaches. The territorial management mechanisms will be participative and not just normative, integrating physical planning and economic development.

Public actions directed at rural territories are determined by information and, in particular, by indicators that do not agree with the scale of needs and contributions that rural territories have and make; therefore, the methodology contemplated addresses the productive activities of people immersed in the rural context and their action and interaction as components of the territory system. To reach this purpose, a diagnosis of the potentials that the communities selected have is carried out and it is later linked to the actions of the programs that are applied, in order to be able to identify in which way they participate in the development process of the communities of study ${ }^{3}$. 
Para alcanzar este propósito se realiza un diagnóstico de los potenciales que poseen las comunidades seleccionadas y se liga posteriormente con las acciones de los programas que se aplican, a fin de poder identificar en qué forma participan del proceso de desarrollo de las comunidades de estudio ${ }^{3}$.

El esquema de análisis aborda al desarrollo rural desde el enfoque territorial, planteando la situación de un territorio y sus dinámicas, tal y como señalan autores como Sepúlveda et al. (2003), Delgadillo (2004), De Janvry y Sadoulet (2004), Schejtman y Berdegué (2004), Quispe (2006), Echeverri y Echeverri (2009), entre otros, que consideran al territorio como el resultado de un proceso multifactorial compuesto por las condiciones en que se encuentran los recursos, la distribución de los modos de vida de la sociedad, la disponibilidad de conocimientos especializados adecuados, la eficiencia de la administración local, la eficacia de los vínculos entre territorios y la capacidad relativa de la gente de participar en mercados locales, nacionales o internacionales.

\section{Selección de las unidades territoriales y elección metodológica}

$\mathrm{Al}$ enfoque de gestión territorial descrito en el apartado dos se agrega también para el análisis y la definición de la metodología, el enfoque del Desarrollo Económico Territorial (DET), con base en lo propuesto por Francisco Alburquerque en 1994 y modificado por el autor en 2007, quien define que el desarrollo económico depende de la capacidad de integrar el aprovechamiento de los recursos disponibles y potenciales, a fin de satisfacer las necesidades y los problemas básicos de un territorio. Se considera la recolección de información que aporte elementos para el análisis de los potenciales de desarrollo económico territorial, las acciones para la construcción de un entorno innovador, y las fases y actuaciones en apoyo a las actividades generadoras de crecimiento económico y empleo productivo. El análisis se compone de objetivos, recursos disponibles, agentes que promueven el desarrollo y el proceso de planificación en sí mismo.

Los objetivos son fundamentalmente el mejoramiento del empleo y calidad de vida de la población y la elevación de la equidad social. El logro de ellos depende de una transformación del sistema productivo territorial, fomento a la diversificación productiva e incremento del valor agregado. En cuanto a los
The analysis scheme addresses rural development from the territorial approach, suggesting the situation of a territory and its dynamics, just as the following authors point out: Sepúlveda et al. (2003), Delgadillo (2004), De Janvry and Sadoulet (2004), Schejtman and Berdegué (2004), Quispe (2006), Echeverri and Echeverri (2009), among others, who consider the territory as the result from a multifactorial process composed of the conditions in which the resources are found, the distribution of the livelihoods of the society, the availability of adequate specialized knowledge, the efficiency of the local administration, the efficacy of the links between territories, and the relative capacity of people to participate in local, national or international markets.

\section{Selection of the territorial units and methodological selection}

The territorial management approach described in section two is also added for the analysis and the definition of the methodology, the Territorial Economic Development (TED) approach, based on what was proposed by Francisco Alburquerque in 1994 and modified by the author in 2007, who defines that economic development depends on the ability to integrate the exploitation of the available and potential resources, in order to satisfy the needs and basic problems of a territory. The collection of information that contributes elements for the analysis of the potentials for territorial economic development is considered, as well as the actions for the construction of an innovating environment, and the phases and actions in support of the activities that generate economic growth and productive employment. The analysis is composed of objectives, resources available, agents that promote development and the planning process in itself.

The objectives are fundamentally improving employment and the quality of life of the population and increasing social equity. Their achievement depends on a transformation of the territorial productive system, promotion of productive diversification and increase of the added value. In terms of the resources available, they must be used adequately based on a coherent strategy and both for the objectives and for the use of resources it is necessary to consider environmental sustainability. 
recursos disponibles deben utilizarse adecuadamente con base en una estrategia coherente y tanto para los objetivos como para el uso de los recursos es necesario contemplar la sostenibilidad ambiental.

Como lo establece Alburquerque (1994:322), para la planificación del desarrollo económico se considera que existen recursos reales y potenciales, además de las necesidades como elementos orientadores de la planificación del territorio. A partir de la valorización de los potenciales de desarrollo y los recursos locales se configura el entorno socioeconómico e institucional territorial, cuya identificación resulta trascendental.

\section{Caracterización de las unidades de análisis}

La determinación de las unidades de análisis parte de la hipótesis de que los estudios realizados en el territorio empleados en el diseño de las políticas públicas revelan de manera limitada las interacciones que se ubican en su interior y entre territorios comunes. Para la observación se estableció una comparación inter-territorial a partir de dos territorios localizados en los estados de Guerrero y Oaxaca, específicamente en los municipios de San Juan del Río (San Juan) y Tecpan de Galeana (Figura 1). El primero de ellos, de acuerdo con las relaciones socioespaciales y el tamaño de su población, contempló toda el área geográfica y administrativa del municipio, mientras que en el segundo caso se eligieron dos localidades: San Luis de la Loma y San Luis San Pedro, identificadas como los San Luises en la región y por sus habitantes. Los sujetos de la investigación, es decir, los actores, son los habitantes que realizan las actividades productivas que caracterizan a cada uno de estos territorios.

San Juan del Río se localiza en la región de los Valles Centrales de Oaxaca; pertenece al distrito de Tlacolula de Matamoros, con una extensión de $108 \mathrm{~km}^{2}$, que representa $0.12 \%$ de la superficie total de la entidad federativa. Se ubica a una altitud de $1180 \mathrm{~m}$, a $95 \mathrm{~km}$ de la ciudad capital. Los principales centros de abasto para esta comunidad son el municipio de Tlacolula y la ciudad de Oaxaca. El municipio de Mitla (fuera del entorno regional) juega también un papel importante ya que es uno de los principales puntos de venta de los productos que se generan en la comunidad.

De acuerdo con el XIII Censo de Población y Vivienda 2010 del INEGI, la población total del municipio de San Juan del Río es de 1231 habitantes y
As Alburquerque (1994:322) establishes, for the planning of economic development it is considered that there are real and potential resources, in addition to the needs as orienting elements of territory planning. From the valuation of the potentials for development and the local resources, the territorial socioeconomic and institutional environment is shaped, whose identification turns out to be significant.

\section{Characterization of the units of analysis}

The determination of the units of analysis stems from the hypothesis that the studies carried out in the territory used in the design of public policies reveal in a limited way the interactions that are found inside them and between common territories. For the observation, an inter-territorial comparison was established from two territories located in the states of Guerrero and Oaxaca, specifically in the municipalities of San Juan del Río (San Juan) and Tecpan de Galeana (Figure 1). The first of these, according to the socio-spatial relationships and the size of their population, contemplated the whole geographic and administrative area of the municipality, while in the second case two localities were chosen: San Luis de la Loma and San Luis San Pedro, identified as the San Luises in the region and because of their inhabitants. The research subjects, that is, the actors, are the inhabitants that perform

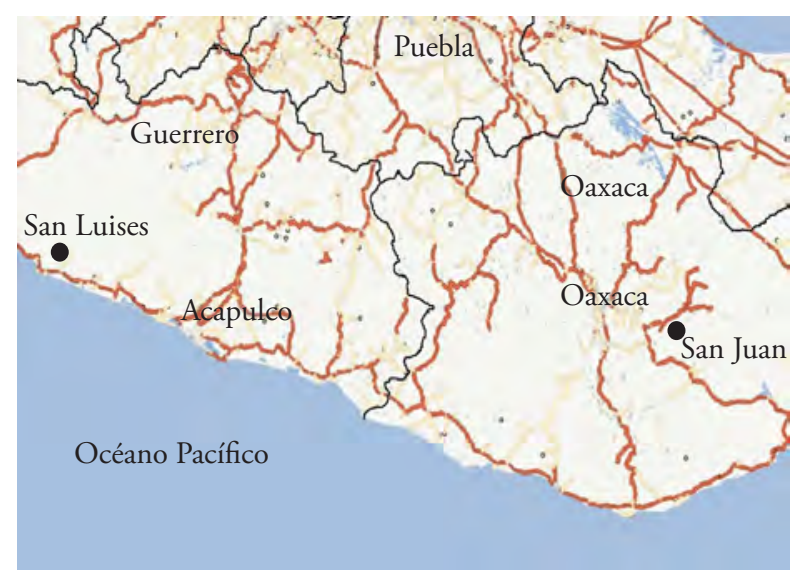

Fuente: elaboración propia. * Source: authors' elaboration.

Figura 1. Localización de los territorios de estudio. Figure 1. Location of the territories of study. 
está compuesta mayormente por una población de indígenas zapotecos, hablantes de la variante dialectal del valle. Pese a que no posee atractivos turísticos desarrollados o recursos naturales, dicho territorio, para conformarse como una región agrícola-pecuaria fuerte, cuenta con una población que conserva la tradición de realizar dos productos de origen artesanal, que son mezcal y tejidos a base de ganchillo de diversa índole, como algunas de sus principales actividades productivas. No obstante lo anterior, las actividades económicas carecen de fortaleza para su desenvolvimiento y se registra una alta migración.

Con un grado de marginación alto ${ }^{4}$, la población depende en buena medida de las transferencias públicas que se realizan a través de programas de asistencia. En este sentido, un ejemplo de ello son los programas de SEDESOL, que a 2013 incide en la comunidad con cuatro programas, resultando el más relevante Oportunidades, con 147 familias beneficiarias registradas en 1999 y hasta 2012, y $41 \%$ de población beneficiaria en la comunidad.

Por otra parte, el municipio de Tecpan, en el estado de Guerrero, se localiza a 120 metros sobre el nivel del mar, al suroeste de Chilpancingo; cuenta con $2537.8 \mathrm{~km}^{2}$ que representan $3.98 \%$ de la superficie total del Estado. Colinda al norte con Coyuca de Catalán y Ajuchitlán del Progreso, al este con Atoyac de Álvarez y Benito Juárez, al sur con el océano Pacífico, y al oeste con Petatlán.

Los San Luises están ubicados a $20 \mathrm{~m}$ de altitud en promedio y a una distancia aproximada de $34 \mathrm{~km}$ de Tecpan, que es la cabecera municipal. Sus principales relaciones son con la localidad contigua de Nuxco y el mismo Tecpan. Las actividades económicas de la comunidad se dividen en dos tipos, las tradicionales que han formado parte de su estructura productiva, que son la producción de ganado mayor y la producción coprera de suma relevancia para la entidad en general, mientras que de reciente incorporación se registra el procesamiento de lácteos y la producción de mango, con alto impacto por la importancia de la región en su cultivo a nivel nacional.

Sumando la población de ambas localidades, en 2010 se registraron 9321 habitantes, con un grado de marginación alto para ese mismo año, según el CONAPO. La población recibe apoyos del programa Oportunidades, que registra 39 \% de la población de la comunidad como beneficiaria, con 787 familias; asimismo, participan en cuatro programas más de la SEDESOL. productive activities that characterize each one of these territories.

San Juan del Río is located in the region of the Central Valleys of Oaxaca; it belongs to the district of Tlacolula de Matamoros, with an area of $108 \mathrm{~km}^{2}$, which represents $0.12 \%$ of the state's total surface. It is located at an altitude of $1180 \mathrm{~m}, 95 \mathrm{~km}$ away from the capital city. The main supply centers for this community are the municipality of Tlacolula and the city of Oaxaca. The municipality of Mitla (outside the regional surroundings) also plays an important role since it is one of the main selling points of the products generated in the community.

According to the $13^{\text {th }}$ Population and Housing Census 2010 by INEGI, the total population of the municipality of San Juan del Río is 1231 inhabitants and is composed mostly by a population of Zapotec indigenous people, who speak the dialect variant from the valley. Despite not having tourist attractions developed or natural resources, this territory, in order to become a strong agricultural-livestock region, has a population that conserves the tradition of elaborating two products of artisanal origin, which are mezcal and crochet knits of various kinds, as some of their main productive activities. Despite this, the economic activities lack strength for their development and there is high migration.

With a high degree of marginalization ${ }^{4}$, the population depends to a great degree on the public transferences that are done through assistance programs. In this sense, SEDESOL programs are an example of this, which by 2013 influence the community with four programs, Oportunidades being the most relevant, with 147 beneficiary families recorded in 1999 and until 2012, and $41 \%$ of beneficiary population in the community.

On the other hand, the municipality of Tecpan, in the state of Guerrero, is located 120 meters above sea level, southwest of Chilpancingo; it has 2537.8 $\mathrm{km}^{2}$ of area that represent $3.98 \%$ of the total surface of the state. It borders north with Coyuca de Catalán and Ajuchitlán del Progreso, east with Atoyac de Álvarez and Benito Juárez, south with the Pacific ocean, and west with Petatlán.

The San Luises are located at $20 \mathrm{~m}$ of altitude in average and at an approximate distance of $34 \mathrm{~km}$ from Tecpan, which is the municipal seat. Their main relations are with the neighboring locality of Nuxco and with Tecpan. The economic activities 
En el territorio, los habitantes de los San Luises reconocen una relación que los liga íntimamente, ya que la infraestructura básica y de equipamiento ha sido compartida por sus pobladores prácticamente desde su formación. Las relaciones principales de abasto y productivas, así como de dotación de servicios (salud y educación por ejemplo), se realizan con las ciudades de Acapulco y Zihuatanejo. Pese a que el recorrido a la ciudad de Chilpancingo es mayor, existe una importante relación derivada primordialmente de los servicios de abasto y la necesidad de resolver asuntos con las instituciones públicas que ahí se localizan.

\section{Elección MetodológicA}

El territorio es un espacio donde se interrelacionan procesos productivos, ambientales, sociales, culturales y políticos. Es construido por uso y apropiación, y la acción formativa se encuentra articulada a procesos de vida y trabajo, percepciones e identidades territoriales. A partir de esta conceptualización se parte en el esquema de trabajo de la definición de la variable principal a la cual hemos denominado potenciales de desarrollo en la comunidad, y la determinación de seis dimensiones complementarias compuestas por un conjunto de variable de indicadores que se describen más adelante (Figura 2). El supuesto del modelo parte de la consideración de que en la medida en que estos elementos son aprovechados pueden incidir favorablemente en la condición de vida de los pobladores. La integración a partir de distintas dimensiones no implica una mera suma de componentes, ya que todos los indicadores están relacionados con uno o más de los mismos y derivan de los recursos, las funciones y las relaciones que en el territorio se identifican.

Las funciones y relaciones en la comunidad se abordan a través del análisis de las características del entorno medioambiental, sociodemográficas, las relaciones económico-productivas y la infraestructura física con que se desenvuelven las actividades de los habitantes, poniendo énfasis en los procesos productivos e incorporando a la observación los programas públicos o privados que inciden en las comunidades. En este sentido, se toma en cuenta la percepción y ejecución de los actores del territorio, así como la disposición a la participación en los mismos, como elemento que facilite la aplicación de los instrumentos in the community are divided into two types, the traditional which have been part of their productive structure, which are the production of large livestock and the copra production of great relevance for the entity at large, while dairy processing and mango production are of recent incorporation, with high impact because of the importance in the region in their cultivation at the national level.

Adding the population from both localities, 9321 inhabitants were found in 2010, with a high degree of marginalization for that same year, according to CONAPO. The population receives backing from the Oportunidades program, which records $39 \%$ of the population from the community as beneficiary, with 787 families; likewise, they participate in four more programs from SEDESOL.

In the territory, the inhabitants from the San Luises recognize a relationship that ties them intimately, since the basic infrastructure and equipment has been shared by their inhabitants practically since their formation. The main relationships of supply and production, as well as the supply of services (health and education, for example), are carried out with the cities of Acapulco and Zihuatanejo. Despite the journey to the city of Chilpancingo being longer, there is an important relationship derived primarily from the supply services and the need to resolve issues with the public institutions located there.

\section{Methodological Selection}

The territory is a space where productive, environmental, social, cultural and political processes are interrelated. It is built by use and appropriation, and the formative action is articulated to life and work processes, territorial perceptions and identities. From this conceptualization, the working scheme stems from the definition of the principal variable which we have called development in the community, and the determination of six complementary dimensions made up of a set of variables of indicators that are described later (Figure 2). The assumption of the model starts from the consideration that as these elements are taken advantage of they can influence favorably the living conditions of the inhabitants. The integration from different dimensions does not imply a mere sum of components, since all the indicators are related to one or more of these and derive from the resources, the functions, and the relations identified in the territory. 


\begin{tabular}{|c|c|}
\hline Variable & Dimensión \\
\hline \multirow{6}{*}{ 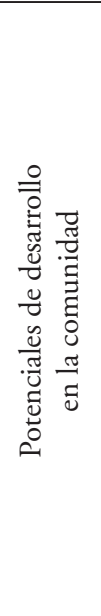 } & $\begin{array}{l}\text { Potencial Medioambiental de Desarrollo } \\
\text { Características del entorno medioambiental, rasgos físicos del territorio }\end{array}$ \\
\hline & $\begin{array}{l}\text { Potencial Material de Desarrollo } \\
\text { Diagnóstico de la infraestructura básica y la vivienda: características, volumen y calidad. }\end{array}$ \\
\hline & $\begin{array}{l}\text { Potencial Productivo de Desarrollo } \\
\text { Unidades encargadas de organizar los factores productivos. }\end{array}$ \\
\hline & $\begin{array}{l}\text { Potencial Finaciero de Desarrollo } \\
\text { Unidades encargadas del apoyo o fomento a los factores productivos. }\end{array}$ \\
\hline & $\begin{array}{l}\text { Potencial Capital Humano para el Desarrollo } \\
\text { Capacidades de las personas. }\end{array}$ \\
\hline & $\begin{array}{l}\text { Potencial Capital Social para el Desarrollo } \\
\text { Relaciones y redes. }\end{array}$ \\
\hline
\end{tabular}

Fuente: elaboración propia. Source: authors' elaboration.

Figura 2. Dimensiones para el análisis

Figure 2. Dimensions for the analysis.

y las adecuaciones, ajustes o modificaciones a favor del fortalecimiento del capital social y con ello del territorio en sí mismo (Cuadro 1).

Un enfoque de análisis a través de potenciales permite estimar las capacidades individuales de las organizaciones, redes y sectores productivos, entre otros, para la instrumentación de los métodos, estrategias y programas que aporten elementos para el desarrollo de capacidades, proponiendo los componentes de cada dimensión como sigue:

1. Potencial Medioambiental de Desarrollo. Hace referencia a las características físicas del territorio, es decir, de los recursos naturales, la variación que han tenido estos en los últimos 20 años y los usos recomendables, a fin de establecer la relación y relevancia en las actividades de la comunidad.

2. Potencial Material de Desarrollo. Compuesto por servicios básicos, vivienda y equipamiento, considera establecer las características y usos, disponibilidad y calidad de dichos elementos en el territorio como parte de los activos en la estructura económica y para el desarrollo de la comunidad.

3. Potencial Productivo de Desarrollo. Observa las unidades, actividades y cadenas productivas referidas en la organización y aprovechamiento de los factores productivos que componen la estructura
The functions and relationships in the community are addressed through the analysis of the characteristics of the environmental, sociodemographic surroundings, the economicproductive relations and the physical infrastructure with which the inhabitants' activities develop, placing an emphasis on productive processes and incorporating the public or private programs that influence the communities to the observation. In this sense, the perception and execution of the actors in the territory are taken into account, as well as the disposition to participation in them, as an element that eases the application of the instruments and the adaptations, adjustments or modifications in favor of the strengthening of the social capital, and with it the territory in itself (Table 1).

An approach for analysis through potentials allows estimating the individual capacities of the organizations, networks and productive sectors, among others, for the implementations of the methods, strategies and programs that contribute elements for the development of capacities, proposing the components from each dimension as follows:

1. Environmental Potential for Development. It refers to the physical characteristics of the territory, that is, of the natural resources, the 
Cuadro 1. Esquema de trabajo.

Table 1. Working plan.

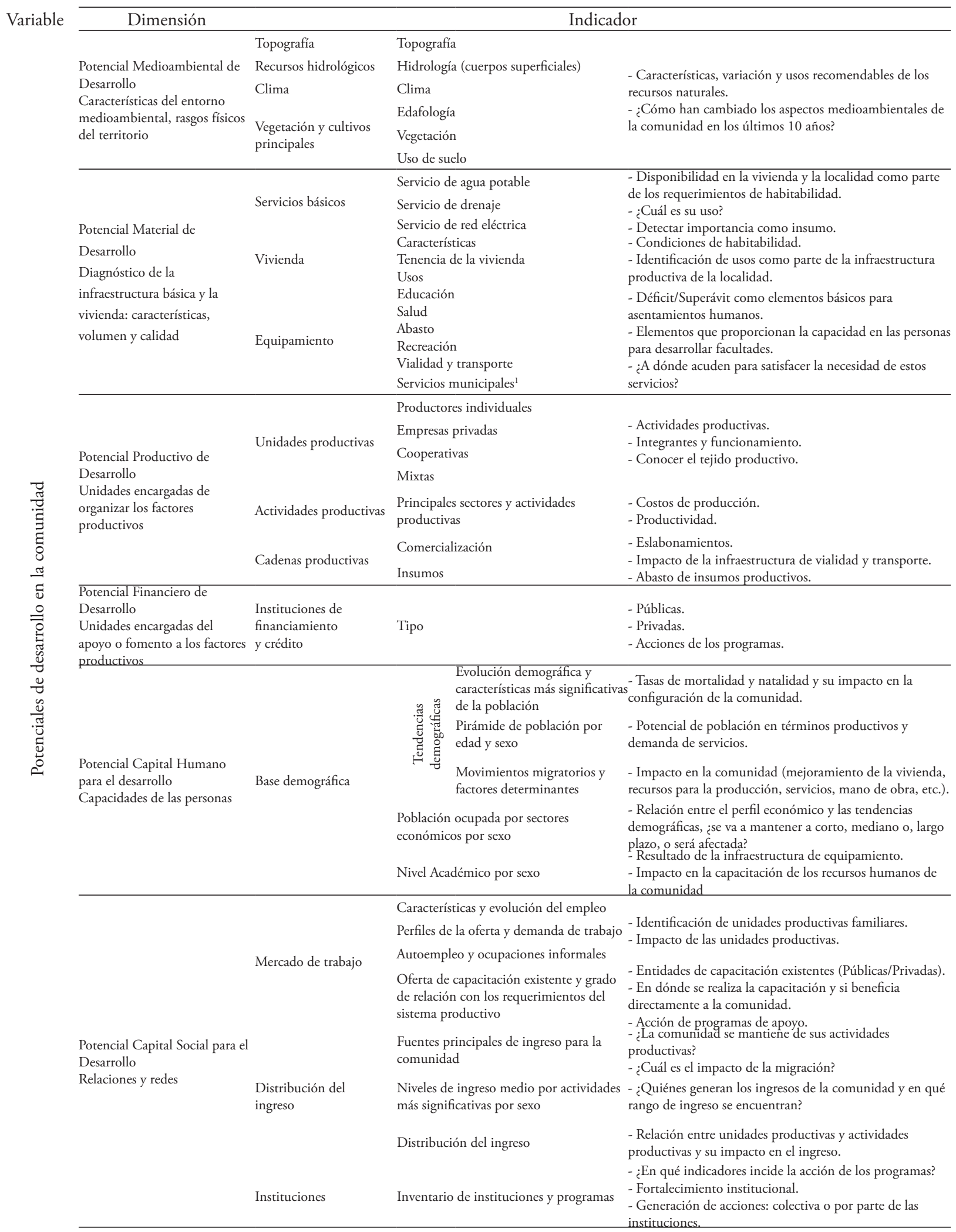

${ }^{1}$ Cementerio, bomberos, policía, basurero municipal, gasolinera. Cemetery, firefighters, police, municipal garbage dump, gas station.

Fuente: elaboración propia. * Source: authors' elaboration. 
productiva en un territorio, así como la acción de los actores con base en sus recursos y habilidades.

4. Potencial Financiero de Desarrollo. Aborda la identificación y caracterización de las unidades con facultad de apoyar el aprovechamiento de los factores productivos de la comunidad, haciendo necesario el reconocimiento de las iniciativas de empresariado existente e instituciones de financiamiento y crédito, ya sean de orden público o privado.

5. Potencial Capital Humano para el Desarrollo. Considera el análisis de la base demográfica y la relación existente con factores productivos, revelando cuáles son las capacidades de los actores y las aptitudes del territorio en su desarrollo.

6. Potencial Capital Social para el Desarrollo. Contempla el análisis de la composición de las relaciones y las redes de los actores en el territorio para el desenvolvimiento de las actividades del territorio, poniendo énfasis en las que cuentan con un carácter colectivo a través de las Unidades de Producción Familiar y los grupos de trabajo. Estos elementos inciden en la composición y relación que tiene el territorio a su interior y con otros territorios.

\section{Los instrumentos y la aplicación del modelo de intervención}

El contenido del esquema de investigación plantea la necesidad de emplear datos cuantitativos y cualitativos, dado que se hará la identificación de cada componente a partir de la presencia y percepción en los habitantes (actores productivos) de los territorios. Los datos cuantitativos contemplan el empleo de fuentes secundarias, mientras que la información cualitativa es resultado de la investigación de campo basada en entrevistas semi-estructuradas.

\section{Análisis descriptivo}

La investigación está planteada en un nivel descriptivo que identifica características, formas de conducta y actitudes; permite establecer comportamientos concretos y descubre y comprueba la asociación entre las variables de la investigación (Castillo de Matheus, Madriz, Márquez y Niño, 2007:118). De esta manera, se describe la situación de los recursos identificados en cada una de las dimensiones, de variation that these have had in the last 20 years, and the uses recommended, in order to establish the relationship and relevance in the community's activities.

2. Material Potential for Development. Composed by basic services, housing and equipment, it considers establishing the characteristics and uses, availability and quality of these elements in the territory as part of the assets in the economic structure and for the community's development.

3. Productive Potential for Development. It observes the units, activities and productive chains described in the organization and the exploitation of the productive factors that make up the productive structure in a territory, as well as the action of actors based on their resources and abilities.

4. Financial Potential for Development. It addresses the identification and characterization of the units with faculty to support the exploitation of the productive factors of the community, making it necessary to recognize the initiatives of the existing entrepreneurs and institutions for financing and credit, whether of public or private order.

5. Human Capital Potential for Development. It considers the analysis of the demographic base and the existing relationship with productive factors, revealing which are the capacities of the actors and the aptitudes of the territories in their development.

6. Social Capital Potential for Development. It contemplates the analysis of the composition of the relationships and the networks of actors in the territory for the development of activities in the territory, placing emphasis in those that have a collective character through the Family Production Units and the working groups. These elements influence the composition and relationship they have inside the territory and with other territories.

\section{The instruments and application of the intervention model}

The content of the research plan suggests the need to use quantitative and qualitative data, given that each component will be identified from the presence and perception in the inhabitants (productive actors) of the territories. The quantitative data contemplate 
acuerdo con los aspectos favorables y desfavorables en el desarrollo del potencial que tienen.

Dado que nos referimos al análisis del proceso de intervención social, se parte del postulado de que las transformaciones estructurales requieren cambios en la manera de concebir los procesos sociales $y$, consecuentemente, en las prácticas de los sujetos involucrados y en sus formas de organización social; por tanto, se propone un esquema de trabajo amplio que considera por cada uno de los potenciales una dimensión. Como señala Coraggio (2004:21-22):

Una concepción adecuada de los procesos sobre los cuales se quiere intervenir para lograr un desarrollo en función de las condiciones de vida de las grandes mayorías deberá conducir al planteamiento de objetivos y políticas integrales, en el sentido de que consideren no solamente los aspectos más directamente vinculados a tales condiciones, sino que penetren en la compleja malla de relaciones con una visualización de su naturaleza procesal y reproductiva.

\section{Investigación de campo}

El diseño de la investigación de campo es un estudio no experimental que, como señalan Hernández, Fernández y Baptista (2001:267), consistió en observar fenómenos, tal y como se dan en su contexto natural para después analizarlos; en este modelo no se construye ninguna situación, sino que se observan situaciones ya existentes. Asimismo, se realiza una investigación de tipo transaccional o transversal que recolecta datos en un solo momento, en un tiempo único y tiene como propósito describir variables y analizar su incidencia e interrelación en un momento dado, por lo que constituye la recolección directa de la situación de los actores productivos del territorio.

La entrevista se aplica con base en un muestreo no probabilístico a través de la técnica "bola de nieve". La idea central de esta es que cada individuo en la población puede nominar a otros individuos en el territorio, los cuales tienen la misma probabilidad de ser seleccionados. Se identifica a los informantes de la primera muestra por referencia directa del entrevistador y se establecen en cada entrevista qué nuevas personas de la población en estudio han de entrevistarse, para así integrar la muestra completa. El supuesto subyacente es que los miembros de la the use of secondary sources, while the qualitative information results from the field research based on semi-structured interviews.

\section{Descriptive analysis}

The study is proposed at a descriptive level that identifies characteristics, forms of behavior and attitudes; it allows establishing concrete behaviors and uncovers and verifies the association between the research variables (Castillo de Matheus, Madriz, Márquez and Niño, 2007:118). Therefore, the situation of the resources identified in each one of the dimensions is described, according to the favorable and unfavorable aspects in the development of the potential they have.

Given that we refer to the analysis of the process of social intervention, we start from the hypothesis that structural transformations require changes in the way of conceiving social processes and, consequently, in the practices of the subjects involved and in their forms of social organization; thus, a broad working scheme is proposed that considers for each of the potentials one dimension. As Coraggio points out (2004:21-22):

An adequate conception of the processes about which there is a need to intervene to achieve development in function of the living conditions of the large majorities should lead to the establishment of integral objectives and policies, in the sense that they consider not only the aspects most directly linked to such conditions, but rather that they penetrate the complex mesh of relationships with a visualization of their procedural and reproductive nature.

\section{Field research}

The design of the field research is a nonexperimental study which, as Hernández, Fernández and Baptista (2001:267) point out, consisted in observing phenomena, just as they take place in their natural context to later analyze them; in this model no situation is constructed, but rather situations that are pre-existing are observed. Likewise, a study of transactional or transversal nature is carried out, where data are collected in a single moment, at a single time, and which has the purpose of 
población que no se encuentra visible no viven en completo aislamiento, es decir, tienen por lo menos una "red social" con la cual es posible contactarlos. Se establecen como unidad de estudio los actores territoriales (productores), puesto que son ellos quienes tienen una visión integral de su territorio, con la capacidad de promover una amplia gama de actividades y desarrollar los potenciales.

\section{Proceso de entrevistas}

El trabajo de campo se realizó en dos momentos, compuestos por dos fases cada uno, durante julio y agosto de 2008. En la primera fase se levantaron entrevistas en las comunidades previamente elegidas mediante el método de selección dirigida de actores clave donde, habiendo seleccionado y establecido contacto con el primer informante clave, se solicitó a este el nombre de otro integrante de la comunidad que realizara alguna actividad económica dentro de la comunidad, con la finalidad de contar con un levantamiento general y poder definir a partir de ello cuáles son las actividades representativas para el estudio. Asimismo, se llevaron a cabo entrevistas con autoridades locales que permitieron visualizar, desde su opinión, el panorama general de la organización funcional del territorio. En una segunda etapa se realizó un levantamiento fotográfico y el registro de los recursos naturales, el estado de las viviendas (que permitió tipificarlas), así como un inventario de la infraestructura básica (agua, servicio eléctrico, drenaje, entre otros), vialidades, equipamiento y servicios en general, con los que la comunidad lleva a cabo sus actividades. Ello implicó acudir a informantes secundarios, tales como encargados del centro de salud en cada comunidad, escuelas y bibliotecas, por ejemplo. El primer momento de este trabajo consistió en la visita a la comunidad de San Juan del Río donde se realizaron 15 entrevistas a informantes clave y alrededor de cinco entrevistas informales para obtener datos secundarios. El segundo momento fue el trabajo de campo correspondiente a los San Luises, donde se obtuvieron 12 entrevistas del primer tipo y tres de la segunda.

Se aplicaron las entrevistas en los hogares o lugares de trabajo, según la conveniencia de los entrevistados, a quienes se informó sobre los objetivos de la investigación, los cuales dieron su aprobación a participar en el trabajo de manera voluntaria. A la información arrojada por las entrevistas se agrega la del describing variables and analyzing their influence and interrelation at a given moment, which is why it constitutes the direct recollection of the situation of the productive actors in the territory.

The interview is applied based on a nonprobabilistic sample through the "snowball" technique. The central idea of this is that each individual in the population can nominate other individuals in the territory, who have the same probability of being selected. The informants from the first sample are identified by direct reference from the interviewer, and in each interview it is established which new people from the population in study will be interviewed, in order to integrate the complete sample. The underlying assumption is that the members of the population that are not visible do not live in complete isolation, that is, they have at least a "social network" with which it is possible to contact them. The territorial actors (producers) are established as a unit of study, since they are the ones that have an integral vision of their territory, with the capacity to promote a broad range of activities and to develop the potentials.

\section{Interviewing process}

The field work was carried out in two moments, made up of two phases each, during July and August 2008. During the first phase, interviews were performed in the communities previously chosen through the method of directed selection of key actors where, having selected and established contact with the first key informant, he was requested to provide the name of another member of the community who performed an economic activity within the community, with the aim of having a general appraisal and being able to define, from this, which are the representative activities for the study. Likewise, interviews were carried out with local authorities that allowed visualizing, based on their opinion, the general landscape of the functional organization of the territory. In a second stage, a photographic appraisal was performed and the registry of natural resources, the status of housing (which allowed typifying them), as well as the inventory of basic infrastructure (water, electric service, drainage, among others), roads, equipment and services in general, with which the community undertakes its activities. This implied resorting to 
diario de campo, que considera prácticas que realizan las comunidades y algunas condiciones situacionales, como información que no fue recogida por medio del instrumento, pero que revela datos importantes en apoyo al análisis y explicación del trabajo. Así pues, cada una de las dimensiones se ve enriquecida por los contenidos de la entrevista.

Con base en el objetivo de este trabajo se busca que las políticas se fundamenten en diagnóstico y prognosis, y recuperen la experiencia acumulada en el pasado, por lo que las tareas de análisis histórico, diagnosis y prognosis están agrupadas en la descripción de los fenómenos (Coraggio, 2004:10). Para tal efecto, la información que compone los indicadores por cada una de las dimensiones proviene en primera instancia de fuentes bibliográficas (primordialmente estadística). A esta información se incorporan las percepciones recogidas con la entrevista y aquellos elementos que resultaron relevantes provenientes de la observación.

\section{Diseño de medición de potenciales}

El procedimiento de análisis para cada uno de los seis potenciales o dimensiones consiste en describir las características por cada comunidad y de sus actividades económicas principales, partiendo de los indicadores que lo componen (Cuadro 2). Se incluye la atención que se registra en cada actividad, refiriéndose a acciones públicas (programas o instituciones que participan), privadas además de otros elementos que responden a esfuerzos realizados por parte de las secondary informants, such as the ones in charge of the health center in each community, schools and libraries, for example. The first moment of this work consisted in the visit to the community of San Juan del Río where 15 interviews were carried out with key informants and around five informal interviews to obtain secondary data. The second moment was the field work in the San Luises, where 12 interviews of the first type were carried out and three of the second.

The interviews were applied in the households or workplaces, based to the convenience of the interview respondents, who were informed about the objectives of the research, who gave their approval to participating in the study voluntarily. In addition to the information obtained from interviews, there was the field diary, which considers the practices that communities perform and some situational conditions, such as information that was not collected through the instrument, but which reveals important data in support of the analysis and explanation of the work. Thus, each one of the dimensions is made richer by the contents of the interview.

Based on the objective of this study, it is sought for policies to be based on diagnosis and prognosis, and for them to recover the experience accumulated in the past, which is why the tasks of historical analysis, diagnosis and prognosis are grouped in the description of the phenomena (Coraggio, 2004:10). For this purpose, the information that makes up the indicators for each of the dimensions comes in first instance from bibliographic sources (mainly

Cuadro 2. Análisis por Potencial de Desarrollo.

Table 2. Analysis by Potential for Development.

\begin{tabular}{|c|c|c|c|c|}
\hline Comunidad & Actividades & $\begin{array}{c}\text { Indicadores } \\
\text { Características } \\
\end{array}$ & Atención & $\begin{array}{l}\text { Tipo de } \\
\text { activida }\end{array}$ \\
\hline San Juan & $\begin{array}{l}\text { Cultivo de maguey y } \\
\text { producción de mezcal } \\
\text { Tejidos }\end{array}$ & $\begin{array}{l}\text { Potencial medioambiental de desarrollo } \\
\text { Potencial material de desarrollo } \\
\text { Potencial productivo de desarrollo } \\
\text { Potencial financiero de desarrollo } \\
\text { Potencial capital humano para el desarrollo } \\
\text { Potencial capital social para el desarrollo }\end{array}$ & $\begin{array}{l}\text { Pública/Privada/ } \\
\text { Iniciativa territorial }\end{array}$ & $\begin{array}{l}\text { Potencial } \\
\text { Motor } \\
\text { Motor- } \\
\text { Potencial }\end{array}$ \\
\hline San Luises & $\begin{array}{l}\text { Mango } \\
\text { Coco } \\
\text { Cría de ganado } \\
\text { bovinos-leche y } \\
\text { elaboración de quesos }\end{array}$ & $\begin{array}{l}\text { Potencial medioambiental de desarrollo } \\
\text { Potencial material de desarrollo } \\
\text { Potencial productivo de desarrollo } \\
\text { Potencial financiero de desarrollo } \\
\text { Potencial capital humano para el desarrollo } \\
\text { Potencial capital social para el desarrollo }\end{array}$ & $\begin{array}{l}\text { Pública/Privada/ } \\
\text { Iniciativa territorial }\end{array}$ & $\begin{array}{l}\text { Potencial } \\
\text { Motor } \\
\text { Motor- } \\
\text { Potencial }\end{array}$ \\
\hline
\end{tabular}

Fuente: elaboración propia. \$ Source: authors’ elaboration. 


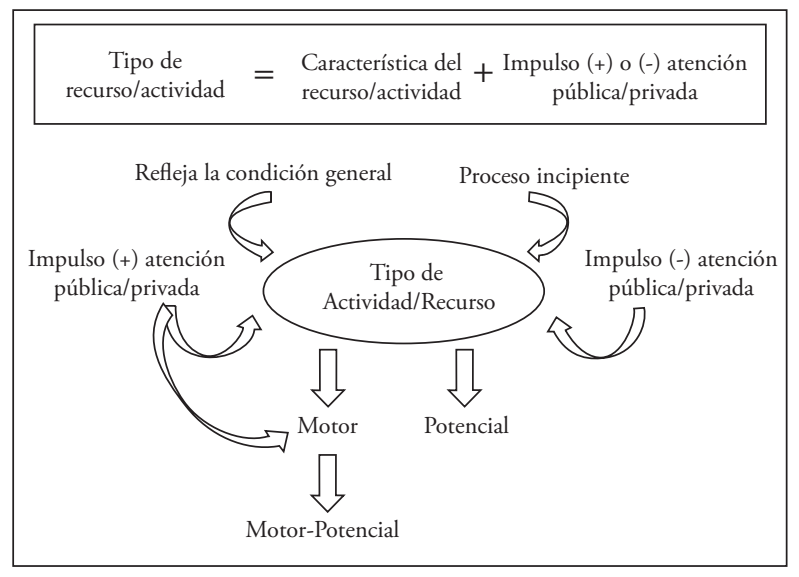

Fuente: elaboración propia. \&ource: authors' elaboration.

Figura 3. Proceso para la determinación de tipo de actividad/ recurso.

Figure 3. Process for the determination of type of activity / resource.

comunidades sin contar con apoyo externo, a lo cual se le denominó iniciativa territorial.

Posteriormente, para identificar la incidencia de los programas encontrados en las comunidades se incluyó el tipo de actividad a que refiere, en síntesis, el estado en que se encuentra una actividad de acuerdo con su desenvolvimiento, respecto del resultado de los indicadores y el apoyo que recibe. Para ello se determinaron actividades motores y potenciales en las que se retoma la propuesta de Castillo et al. (2007:120), denominando actividad motor a aquella que muestra efectivamente la situación de la comunidad. Un ejemplo de ello es que el sector económico que representa la economía del territorio se reconoce como sector de desarrollo, puesto que se concentra en él una parte relevante de la producción actual de la localidad y ha recibido atención pública o privada para su producción permanente (Cuadro 2 y Figura 3).

Por otra parte, las actividades potenciales son aquellas que se identifican también en las comunidades como las que se encuentran en desarrollo incipiente y que, siguiendo el ejemplo anterior, se hallan trabajando, pero no han recibido el impulso requerido para convertirse en actividades motores. Además, se utilizó la denominación de actividad motor-potencial para aquellos recursos representativos, que siendo motor poseen además altas y promisorias condiciones para incrementar su desarrollo. statistical). The perceptions gathered with the interview and those elements that turned out to be relevant from observation were incorporated into this information.

\section{Design in measuring potentials}

The analysis procedure for each one of the six potentials or dimensions consists in describing the characteristics of each community and their main economic activities, stemming from the indicators that make them up (Table 2). The attention given to each activity is included, referring to public actions (programs or institutions that participate), private actions, in addition to other elements that respond to efforts performed by the communities without having external support, which was called territorial initiative.

Later, in order to define the impact of the programs found in the communities, the type of activity which it refers was included; in sum, the state of an activity according to its development, with regards to the result from the indicators and the support it receives. For this purpose, motor and potential activities were determined, where the proposal by Castillo et al. (2007:120) was used, calling motor activity the one that shows the situation of the community effectively. An example of this is that the economic sector that represents the economy of the territory is recognized as the development sector, for a relevant part of the current production of the locality is concentrated in it, and it has received public or private attention for its permanent production (Table 2 and Figure 3).

On the other hand, the potential activities are those that are also identified in the communities such as the ones in incipient development and which, following the previous example, are working but have not received the impulse necessary to become motor activities. In addition, the denomination of motorpotential activity was used for those representative resources, which being a motor also have high and promising conditions to increase their development.

What is being sought is to understand the impact of the proposals (public and private) at present, for the development of the communities. Therefore, the balance of the potentials estimates the individual capacities, those of organizations, networks and productive sectors, among others, that include the conditions in the communities for their implementation, as well as the methods, strategies 
Cuadro 3. Impacto del Tipo de actividad por potencial.

Table 3. Impact of the Type of activity by potential.

\begin{tabular}{|c|c|c|c|c|c|c|c|}
\hline \multicolumn{2}{|r|}{ Comunidad } & \multicolumn{3}{|c|}{ San Juan } & \multicolumn{3}{|c|}{ San Luises } \\
\hline & Actividades & 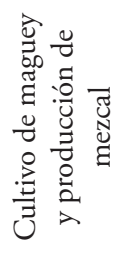 & 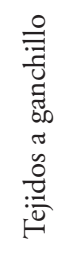 & 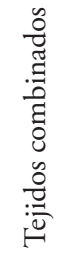 & $\begin{array}{l}0 \\
\stackrel{\infty}{\infty} \\
\sum_{\Sigma}^{\pi}\end{array}$ & $\begin{array}{l}8 \\
0\end{array}$ & 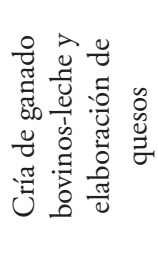 \\
\hline \multirow{7}{*}{ 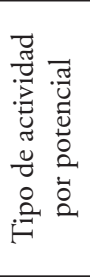 } & Medioambiental & 5 & 4 & 4 & 4 & 4 & 4 \\
\hline & Material & 1 & 1 & 1 & 5 & 3 & 1 \\
\hline & Productivo & 2 & 1 & 5 & 5 & 4 & 3 \\
\hline & Financiero & 1 & 1 & 5 & 5 & 4 & 1 \\
\hline & Capital humano & 1 & 1 & 5 & 5 & 4 & 1 \\
\hline & Capital social & 1 & 1 & 5 & 5 & 4 & 1 \\
\hline & Resumen & 11 & 9 & 25 & 29 & 23 & 11 \\
\hline
\end{tabular}

\begin{tabular}{lc}
\hline Tipo de actividad & Valor \\
\hline Potencial & 1 \\
Motor & 2 a 3 \\
Motor-potencial & 4 a 5 \\
\hline
\end{tabular}

Fuente: elaboración propia. * Source: authors’ elaboration.

Lo que se busca es conocer el impacto de las propuestas (pública y privada) en la actualidad para el desarrollo de las comunidades. Por tanto, el balance de los potenciales estima las capacidades individuales, de las organizaciones, redes y sectores productivos, entre otros, que incluyen las condiciones en las comunidades para la instrumentación, así como de los métodos, estrategias y programas que aporten elementos para el desarrollo de capacidades (Cuadro 3).

\section{Resultados del Análisis}

La aplicación del modelo se llevó a cabo en tres etapas, consistiendo la primera de ellas en el registro del contexto y la recolección de información bibliográfica a través del procesamiento de bases de datos para ambas comunidades. Paralelo a estas actividades se llevó a cabo la identificación y contacto de los informantes clave que permitirían dar inicio al levantamiento de información en campo.

En una segunda etapa se llevaron a cabo las visitas de campo a los territorios, donde se hicieron recorridos para aplicar entrevistas y levantamiento fotográfico para documentar los procesos productivos, el estado de la infraestructura básica y el equipamiento and programs that contribute elements for the development of capacities (Table 3).

\section{RESUlTS FROM THE ANALYSIS}

Application of the model took place in three stages, with the first consisting of recording the context and collecting bibliographic information through the processing of databases for both communities. Parallel to these activities, the identification and contact of key informants was carried out that would allow beginning the appraisal of field information.

In a second stage the field visits to the territories took place, where visits were made to apply interviews and the photographic appraisal was done to document the productive processes, the state of the basic infrastructure and the equipment and natural resources, among other indicators. The interview respondents were primarily producers from the communities although local authorities and public officials were also approached. The third stage consisted in transcribing information from the interviews, and in processing and analyzing the results from the first and second stages in the matrices designed for that purpose. 
y los recursos naturales, entre otros indicadores. Los entrevistados fueron primordialmente productores de las comunidades aunque también se recurrió a autoridades locales y funcionarios públicos. La tercera etapa consistió en la transcripción de información de las entrevistas y el procesamiento y análisis de los resultados de la primera y segunda etapa en las matrices diseñadas para tal fin.

Los resultados de la investigación arrojaron que el acceso y la mayor participación se concentran en escasos programas, predominando específicamente el Procampo, implementado por la Secretaría de Agricultura (SAGARPA) y Oportunidades de la Secretaría de Desarrollo Social (SEDESOL), con espectros de participación limitados que configuran a los territorios como meros beneficiaros de programas que no fomentan en sí el desenvolvimiento de sus estructuras productivas, debido a que son transferencias públicas empleadas para la subsistencia familiar y de los cultivos de autoconsumo que no encuentran eco en otras actividades que permitan el desarrollo del territorio. Se observa asimismo una carente apropiación e identificación con las acciones.

Por otra parte, si bien las vertientes de atención en cada territorio adquieren dimensiones distintas, no reflejan vinculación para el desenvolvimiento de acciones integrales. En este mismo sentido, las figuras de gestión del desarrollo (agencias, prestadores de servicios profesionales, etcétera) se manifiestan bajo un carácter sectorial con impacto insuficiente y marginal.

El desarrollo del trabajo permitió identificar la incidencia de los programas de asistencia y fomento para el desarrollo de los potenciales que llevan a cabo las instituciones y programas públicos y privados, así como acciones implementadas por la propia comunidad (iniciativa territorial).

Con lo anterior se pudo observar que las influencias de la comunidad sobre los procesos propios requieren de un necesario fortalecimiento y apoyo por parte, sobre todo, de las instituciones ya presentes, pese a las ventajas que provee al territorio respecto al arraigo e identificación de los habitantes con las mismas.

Por otra parte, las repercusiones de la relación de las políticas públicas y su actuación diferencia de manera importante las condiciones de los territorios, puesto que el desenvolvimiento de las actividades y el impacto que tienen se encuentran ligados de manera
The results from the research showed that the access and greater participation are concentrated in few programs, with Procampo predominating specifically, which is implemented by the Ministry of Agriculture (SAGARPA), and Oportunidades from the Ministry of Social Development (SEDESOL), with limited fields of participation that establish the territories as mere beneficiaries of programs that do not foster in and of themselves the development of their productive structures, because they are public transferences used for family subsistence and from auto-consumption crops that do not find resonance in other activities that allow the development of the territory. Likewise, a lack of appropriation and identification with the actions is observed.

On the other hand, although the aspects of attention in each territory acquire different dimensions, they do not reflect a connection for the development of integral actions. In this same sense, the figures of development management (agencies, professional services providers, etc.) are manifested under a sectorial character with insufficient and marginal impact.

The development of the work allowed identifying the incidence of the programs of assistance and promotion for the development of the potentials that the institutions and public and private programs carry out, as well as actions implemented by the community itself (territorial initiative).

With this, it could be seen that the influences of the community on their own processes require a necessary strengthening and support by the institutions already present, especially, despite the advantages afforded to the territory with regards to the support and identification of inhabitants with these.

On the other hand, the repercussions of the relationship between public policies and their actions differentiate importantly the conditions of the territories, since the development of the activities and the impact that they have are linked relevantly to the development of the capacities, the potentials, and the strengthening that they have.

The status of the activities that coincide in the conformation of the territory's economy take advantage and potentiate in various ways the pool of resources they have at their disposition, depending in a relevant manner on the capacities developed by the actors, insofar as they find support in their development (Table 4). 
Cuadro 4. Tipo de actividad por potencial.

Table 4. Type of activity by potential.

\begin{tabular}{|c|c|c|c|c|c|c|c|}
\hline \multicolumn{2}{|r|}{ Comunidad } & \multicolumn{3}{|c|}{ San Juan } & \multicolumn{3}{|c|}{ San Luises } \\
\hline & Actividades & 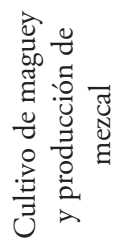 & 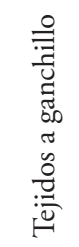 & 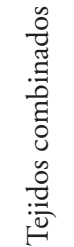 & 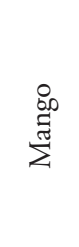 & ن্் & 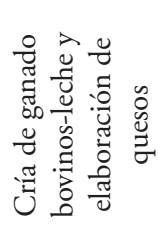 \\
\hline \multirow{7}{*}{ 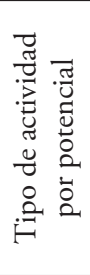 } & Medioambiental & M-P & M-P & M-P & M-P & M-P & M-P \\
\hline & Material & $\mathrm{P}$ & $\mathrm{P}$ & $\mathrm{P}$ & M-P & M & $\mathrm{P}$ \\
\hline & Productivo & M & $\mathrm{P}$ & M-P & M-P & M-P & M \\
\hline & Financiero & $\mathrm{P}$ & $\mathrm{P}$ & M-P & M-P & M-P & $\mathrm{P}$ \\
\hline & Capital humano & $\mathrm{P}$ & $\mathrm{P}$ & M-P & M-P & M-P & $\mathrm{P}$ \\
\hline & Capital social & $\mathrm{P}$ & $\mathrm{P}$ & M-P & M-P & M-P & $\mathrm{P}$ \\
\hline & Resumen & $\mathrm{P}$ & $\mathrm{P}$ & M-P & $\mathrm{M}-\mathrm{P}$ & M-P & $\mathrm{P}$ \\
\hline
\end{tabular}

Tipo de actividad

Potencial P

Motor $\quad \mathrm{M}$

Motor-potencial M-P

Fuente: elaboración propia. * Source: authors’ elaboration.

importante al desarrollo de las capacidades, los potenciales y el fortalecimiento con que cuentan.

El estatus de las actividades que concurren en la conformación de la economía del territorio aprovechan y potencian de diversas formas el acervo de recursos que tienen a su disposición, dependiendo de manera relevante de las capacidades desarrolladas por los actores, toda vez que encuentran apoyo en su desenvolvimiento (Cuadro 4).

Un ejemplo de ello se encuentra en los San Luises, donde la producción agrícola de mango y coco se vislumbra con mejores perspectivas, dado que además de contar con características positivas para el desenvolvimiento en cada una de las dimensiones analizadas se han visto fortalecidas por mecanismos de apoyo gubernamental federal y estatal, además de iniciativas de organización de carácter territorial.

Estos mismos elementos son factores determinantes de diferenciación al interior del territorio y las actividades. En el Cuadro 4 reconocemos que las actividades se encuentran posicionadas en el territorio de acuerdo con la incidencia registrada por programas de apoyo o fomento, así como de las iniciativas territoriales, dando como resultado que los tejidos combinados, la producción de mango y de coco modifican el valor que tienen para el territorio
An example of this is found in the San Luises, where the agricultural production of mango and coconut is surmised to have better perspectives, given that in addition to having positive characteristics for the development in each one of the dimensions analyzed, they have been strengthened by mechanisms of federal and state government support, in addition to organizational initiatives of territorial nature.

These same elements are defining factors of differentiation inside the territory and the activities. In Table 4 we recognize that the activities are positioned in the territory according to the impact found by programs of support or promotion, as well as by territorial initiatives, resulting in the combined knits, the mango and coconut production modifies the value that they have for the territory since they have, specifically, with greater or lesser impact on the mechanisms mentioned. Although they are all considered as activities of motor-potential type, the behavior they present in terms of the impact makes them different.

Being able to reveal the behavior of the economic activities and their potentials, and being able to take them into account in the design and implementation of the proposals for attention towards the territories, allows a public policy of more pertinence, since we 
en tanto cuentan, ya de manera específica, con mayor o menor incidencia de los mecanismos mencionados. Si bien todas son consideradas como actividades tipo motor-potencial, el comportamiento que presentan respecto a la incidencia las hace distintas.

Ser capaces de revelar el comportamiento de las actividades económicas y sus potenciales, y poder tomarlos en cuenta en el diseño e implementación de las propuestas de atención hacia los territorios permite una política pública con mayor pertinencia, puesto que podemos diferenciar entre qué territorios requieren de atención, así como de en qué aspectos y de manera jerárquica. No obstante que el centro de atención de este ejercicio refiere las actividades económicas, las dimensiones involucradas contemplan la posibilidad de conciliar con las propuestas de fortalecimiento de un desarrollo territorial integrado.

\section{Conclusiones}

Una vez llevada a cabo la investigación, el esquema metodológico propuesto demostró ser capaz de revelar información sobre las iniciativas que se implementan en los territorios, rebasando meramente el carácter inventarial de los beneficiarios por cada institución o programa presentes, además de proporcionar información sobre los patrones y perfiles de la participación de los actores. Asimismo, fue posible detectar las relaciones entre dimensiones, es decir, las vertientes atendidas (social, económica, infraestructura, etcétera) e identificar el carácter de las figuras de gestión del desarrollo.

La metodología compuesta por dimensiones e indicadores de análisis es un instrumento que se considera es capaz de evidenciar elementos más específicos componentes del contexto o potencial a desarrollar en los territorios.

La incorporación de la información de las entrevistas como uno de los instrumentos fundamentales resultó en la posibilidad de servir como punto de contraste entre la información pública y la realidad de las comunidades. Las dimensiones territoriales como ejes de análisis permiten propuestas tanto de análisis como de diseño más incluyentes, dado que recaban información detallada de los territorios aportando mayores elementos en la determinación del diseño, instrumentación y evaluación de las políticas públicas aplicadas.

La observación a través de las actividades productivas bajo este esquema permite diferenciar las may differentiate which territories require attention, as well as which aspects and in a hierarchical manner. Although the center of attention of this exercise refers to economic activities, the dimensions involved contemplate the possibility of reconciling with the strengthening proposals for an integral territorial development.

\section{Conclusions}

Once the study was carried out, the methodological plan proposed proved being capable of revealing information about the initiatives that are implemented in the territories, going beyond the mere inventory character of the beneficiaries for each institution or program present, in addition to providing information about the patterns and participation profiles of the actors. Likewise, it was possible to detect the relationships between dimensions, that is, the aspects addressed (social, economic, infrastructure, etc.) and to identify the character of the figures of development management.

The methodology made up of dimensions and indicators of analysis is an instrument that is considered capable of evidencing more specific elements that are part of the context or potential to be developed in the territories.

The incorporation of the information from the interviews as one of the fundamental instruments resulted in the possibility of serving as a contrasting point between public information and the reality of the communities. The territorial dimensions as axes of analysis allow proposals both of analysis and of design that are more inclusive, since they gather detailed information from the territories contributing greater elements to the determination of the design, implementation and evaluation of the public policies applied.

Observation through the productive activities under this plan allows differentiating the conditions in which they are or those from the territory where they are found. With the proposal of the territorial approach based on the analysis by dimensions (environmental, material, etc.) as transversal axes, it is accepted to establish criteria to promote more inclusive and broad relations of the territories that exceed productive vocations or urban hierarchies, for example.

Specifically, the development of this research recognizes in the programs of support and rural 
condiciones en que se encuentran las mismas o las del territorio en que están inscritas. Con la propuesta del enfoque territorial basado en el análisis por dimensiones (medioambiental, material, etcétera) como ejes transversales se concede establecer criterios para promover relaciones más incluyentes y amplias de los territorios que rebasen vocaciones productivas o jerarquías urbanas, por ejemplo.

De manera específica, el desarrollo de la investigación reconoce en los programas de apoyo y fomento rural un aporte que no logra desarrollar por completo su potencial, con una incidencia no solamente menor, sino que provoca desequilibrios en la estructura productiva y del territorio en su conjunto. Con la aplicación del enfoque del desarrollo económico territorial a la propuesta metodológica se demuestra la necesidad que existe de generar sinergias entre las diferentes áreas de la política pública que inciden en un mismo territorio.

\section{Notas}

${ }^{1}$ Las economías de recursos naturales y de transformación de recursos naturales son denominadas por Rafael Echeverri como las basadas en la agricultura, ganadería, pesca, minería, agroecoturismo y servicios ambientales en el caso de las primeras, y la artesanía y agroindustria como las de transformación. Echeverri, en Sepúlveda, Rodríguez, Echeverri y Portilla (2003). The economies of natural resources and transformation of natural resources are called by Rafael Echeverry as those based on agriculture, livestock production, fishing, mining, agroecotourism and environmental services in the first case, and craftsmanship and agroindustry as those of transformation. Echeverri, in Sepúlveda, Rodríguez, Echeverri and Portilla (2003).

${ }^{2}$ El concepto de interacción socioespacial aquí utilizado es distinto al concepto clásico de interacción espacial desarrollado por la geografía económica desde el siglo XIX. Los modelos de interacción espacial stricto sensu se refieren al estudio de los flujos efectivos que se establecen entre las unidades territoriales en el transcurso de un período de tiempo y tienden a relacionarles a un conjunto de modelos de posición que describen, no las relaciones entre dos lugares, sino la posición relativa de un lugar con respecto a los otros. En nuestro caso, al elemento de accesibilidad espacial implícito en el proceso de interacción promotion a contribution that does not manage to develop completely their potential, with an impact that is not only lower, but which causes imbalances in the productive structure and in the territory as a whole. With the application of the approach of territorial economic development to the methodological proposal, the need to generate synergies between the different areas of the public policy that impact a territory is shown.

$$
\text { - End of the English version - }
$$

en un territorio o entre territorios agregamos el valor endógeno dinámico que tienen las organizaciones sociales, comunitarias, productivas, institucionales, gubernamentales, etcétera, como factor potencial del territorio o la región en cuestión. The concept of socio-spatial interaction used here is different from the classical concept of spatial interaction developed by economic geography since the 19th century. The models of spatial interaction stricto sensu refer to the study of the effective flows that are established between territorial units in the course of a period of time and tend to be related to a set of position models that describe, not the relationships between two places, but rather the relative position of a place with regards to the others. In our case, to the element of spatial accessibility implicit in the interaction process in a territory or between territories we add the endogenous dynamic value that social, community, productive, institutional, governmental, etc., organizations have, as a potential factor of the territory or the region in question.

${ }^{3}$ Cabe aclarar que además de los programas de apoyo y fomento rural se consideran también los programas de asistencia. Si bien los objetivos de los programas de asistencia van encaminados hacia otros propósitos; sus resultados implican presumiblemente un impacto en las economías rurales, por lo cual no pueden excluirse, además de ser factor que incide en la organización de los actores, en cuanto a la generación de capital humano se refiere. It should be clarified that in addition to the programs for support and rural promotion, the programs of assistance are also considered. Although the objectives of the programs of assistance are directed at other purposes, their results presumably imply an impact on the rural economies, 
for which they cannot be excluded, in addition to being a factor that impacts the organization of the actors, insofar as the generation of human capital. ${ }^{4}$ Según cálculos del Consejo Nacional de Población (CONAPO) para el año 2010. According to calculations by the National Population Council (Consejo Nacional de Población, CONAPO) for the year 2010.

\section{Agradecimientos}

El presente trabajo contó con el respaldo de la Dirección General de Asuntos del Personal Académico de la UNAM a través del proyecto PAPIITIN300914.

\section{Literatura Citada}

Alburquerque, Francisco. 1994. Metodología para el Desarrollo Económico Local. In: Del Castillo, J. (Ed.), Manual de Desarrollo Local, Serie Estudios de Economía, Departamento de Economía y Hacienda, Vitoria, País Vasco, España: pp: 313-326.

Alburquerque, Francisco. 2007. Desarrollo económico y territorio: Enfoques teóricos relevantes y reflexiones derivadas de la práctica. In: García Docampo, M. (ed), Perspectivas teóricas en desarrollo local. Netbiblo S. L., La Coruña, España: pp: 59-76, 2007.

Calva, José Luis. 2004. Ajuste estructural y TLCAN: Efectos en la agricultura mexicana y reflexiones sobre el ALCA. El Cotidiano, 19 (124), México: 14-22.

Castillo de Matheus, María Elizabeth, Delia Alejandra Madriz, Mervyn Yornney Márquez, y Luisa Valentina Nińo. 2007. Detección de las potencialidades municipales. Una vía para generar desarrollo local. Provincia, 18, Caracas, Venezuela: 115-135.

Coraggio, José Luis. 2004. La gente o el capital. Desarrollo local y Economía del Trabajo. Centro de Investigaciones CIUDAD, Quito-Ecuador.

De Janvry, Alain y Elisabeth Sadoulet. 2004. Hacia un enfoque territorial del desarrollo rural. Cuarto Foro Temático Regional de América Latina y el Caribe, San José, Costa Rica.

Delgadillo, Javier. 2002. Enfoque territorial para la investigación del medio rural. Una aproximación metodológica microrregional. In: Revista Notas núm. 18, INEGI, México, 49-60.
Delgadillo, Javier. 2004. Planeación territorial, políticas públicas y desarrollo regional en México. México: CRIM/DGAPA/ UNAM.

Delgadillo, Javier. 2006. Nuevas opciones para generar empleos e ingresos en el medio rural. Serie Cuadernos Técnicos de Desarrollo Rural, IICA, San José, Costa Rica.

Echeverri, Rafael, y A. Echeverri. 2009. El enfoque territorial redefine el desarrollo rural. Seminario Institucionalidad Agropecuaria y Rural: FAO, Santiago, Chile, febrero.

Elizalde, A. 2003. Planificación estratégica territorial y políticas públicas para el desarrollo local. CEPAL-SERIE Gestión Pública, Instituto Latinoamericano y del Caribe de Planificación Económica y Social (ILPES), número 29, Santiago, Chile, febrero.

FAO. 2005. Un enfoque para el desarrollo rural: Desarrollo Territorial Participativo y Negociado (DTPN). Dirección de Desarrollo Rural.

Hernández, R., C. Fernández, y P. Baptista. 2001. Metodología de la Investigación. México: McGraw-Hill.

Lee, Jimena. 2012. Los programas de asistencia y fomento rural y su incidencia en el desarrollo de las comunidades de San Juan del Río, Oaxaca y Tecpan de Galeana, Guerrero. Tesis de maestría no publicada, Universidad Autónoma del Estado de Morelos, Morelos, México.

Horton, Douglas. 2008. Evolution of Evaluation in International Agricultural Research: The CGIAR Experience. In: European Evaluation Society Conference - Building for the future: Evaluation in governance, development and progress. Lisbon, Portugal.

Quispe, A. 2006. La necesidad de formación de capacidades para la gestión del Desarrollo Rural Territorial. Región y Sociedad, Vol. 18, número 36, 177-194.

Sepúlveda, S., A. Rodríguez, R. Echeverri, y M. Portilla. 2003. El enfoque territorial de desarrollo rural. San José-Costa Rica: IICA.

\section{Fuentes electrónicas}

Grasland, C. 2013. Spatial interaction. Hypergeo, http://www. hypergeo.eu/spip.php?article179

INCA Rural. 2009. Marco conceptual y Modelo Metodológico. http://www.inca.gob.mx/flash_paginas/docs/enfoques/MarcoConceptualMetodologico.pdf

Schejtman, A., y J. Berdegué. 2004. Desarrollo territorial rural. Debates y temas rurales. Centro Latinoamericano para el Desarrollo Rural. http://www.rimisp.org/getdoc. php?docid $=870$ 